\title{
Erratum to: A Retrospective Observational Study of Dicentric (9;12): A Unique, Nonrandom Translocation Defining a Cytogenetic Subgroup with Favorable Outcome in Acute Lymphoblastic Leukemia
}

\author{
S. Shanthala ${ }^{1} \quad$ B. L. Kavitha ${ }^{1} \quad$ Prasanna Kumari ${ }^{1} \quad$ Vijay C.R. ${ }^{2} \quad$ D. Lokanatha ${ }^{3} \quad$ L. Appaji ${ }^{4}$ \\ Govind Babu ${ }^{3}$ Premalata C. S. ${ }^{5} \quad$ C. Ramachandra ${ }^{6}$
}

${ }^{1}$ Cytogenetics Unit-Department of Pathology, Kidwai Memorial Institute of Oncology, Bengaluru, Karnataka, India

Address for correspondence S. Shanthala, MD, \#789, 9th A Main,

2Department of Biostatistics, Kidwai Memorial Institute of Indiranagar 1st Stage, Bangalore, Karnataka, 560038, India

Oncology, Bengaluru, Karnataka, India

${ }^{3}$ Department of Medical Oncology, Kidwai Memorial Institute of

Oncology, Bengaluru, Karnataka, India

${ }^{4}$ Department of Pediatric Oncology, Kidwai Memorial Institute of

Oncology, Bengaluru, Karnataka, India

${ }^{5}$ Department of Pathology, Kidwai Memorial Institute of Oncology, Bengaluru, Karnataka, India

${ }^{6}$ Kidwai Memorial Institute of Oncology, Bengaluru, Karnataka, India

Ind J Med Paediatr Oncol (e-mail: drshanthalas@gmail.com).

\section{Erratum}

The authors have informed the Publisher about an update in the presentation of the fourth author's name. The DOI of the original article is $10.1055 / \mathrm{s}-0041-1732859$, published online on October 5, 2021.

Author name Vijay Kumar should be read as "Vijay C.R." The name has been corrected above and in the original article.

DOI https://doi.org/ $10.1055 / s-0042-1743292$ ISSN 0971-5851
(C) 2021. Indian Society of Medical and Paediatric Oncology. This is an open access article published by Thieme under the terms of the Creative Commons Attribution-NonDerivative-NonCommercial-License, permitting copying and reproduction so long as the original work is given appropriate credit. Contents may not be used for commercial purposes, or adapted, remixed, transformed or built upon. (https://creativecommons.org/licenses/by-nc-nd/4.0/).

Thieme Medical and Scientific Publishers Private Ltd. A-12, Second

Floor, Sector -2, NOIDA -201301, India 